\title{
PENGARUH KOMUNIKASI DAN MOTIVASI TERHADAP KUALITAS PELAYANAN PEGAWAI PADA PUSKESMAS TALISE KOTA PALU
}

\author{
REZKI \\ HARNIDAWAHYUNIADDA \\ YOBERTHKORNELIUS \\ Program Studi S1 Manajemen, FakultasEkonomi, UniversitasTadulako \\ Email: Rezki4652@gmail.com; Harnidaadda@gmail.com; Yoberthkornelius@yahoo.com;
}

\begin{abstract}
The aim of this study is to find out and analyze the effect of communication and motivation on the quality of service employees in Talise City of Palu City. The sample used in this study was 73 employees at the Thalise Health Center in Palu City. The method used in this study is multiple linear regression. Based on the t-test conducted and the results of the regression analysis, the communication and motivation variables have a positive and significant effect on the quality of employee services at the Thalise Health Center in Palu City. Determination test shows R-square value of $76.5 \%$ which means that service quality variables are influenced by independent variables namely communication and motivation while the remaining $23.5 \%$ is influenced by other variables not examined in this study.
\end{abstract}

Keywords: communication, motivation, service quality.

\begin{abstract}
ABSTRAK
Tujuan dari penelitian ini adalah untuk mengetahui dan menganalisis pengaruh komunikasi dan motivasi terhAdap kualitas pelayanan pegawai pada Puskesmas Talise Kota Palu.Sampel yang digunakan dalam penelitian ini adalah berjumlah 73 pegawai di PuskesmasTalise Kota Palu.Metode yang digunakan dalam penelitian ini adalah regresi liniear berganda. Berdasarkan uji t yang dilakukan dan hasil analisis regresi, variabel komunikasi dan motivasi berpengaruh positif dan signifikan terhadap kualitas pelayanan pegawai di PuskesmasTalise Kota Palu. Uji determinasi memperlihatkan nilai R-square sebesar 76,5\% yang berarti bahwa variabel kualitas pelayanan di pengaruhi oleh variabel independen yaitu komunikasi dan motivasi sedangkan sisanya $23,5 \%$ dipengaruhi oleh variabel lain yang tidak dikaji dalam penelitian ini.
\end{abstract}

Kata kunci: komunikasi, motivasi, kualitas pelayanan.

\section{PENDAHULUAN}

Sumber Daya Manusia (SDM) menekankan manusia sebagai pusat dari segalah hal demi menciptakan keberhasilan setiap usaha yang akan dilakukan, sehingga setiap tenaga manusia baik pikiran, kreatifitas, dan daya cipta yang juga merupakan cerminan mutu manusia, harus dapat diupayakan serta digunakan seoptimal mungkin agar dapat meningkatkan kualitas pelayanan. Beberapa faktor yang mempengaruhi kualitas pelayanan diantaranya yaitu komunikasi dan motivasi.

Komunikasi adalah faktor yang sangat penting dalam mencapai suatu tujuan dalam organisasi atau Puskesmas. Secara umum, komunikasi diartikan sebagai proses menyampaikan dan mengirimkan pesan untuk mencapai pemahaman bersama (Richard 2009 dalam Noor 2013). Menurut Robbins 1996 (dalam sehfudin, 2011) mengatakan bahwa komunikasi adalah sebuah pentransferan makna dan informasi maupun pemahaman makna dan informasi kepada orang lain dalam bentuk lambang, bahasa, dan simbol. sehingga seseorang yang memperoleh informasi yang dapat memahami maksud dari informasi tersebut. Menurut James G.Robbins dan Barbara S.Jones 1982 (dalam Sehfudin 2011), dalam buku effective for today manajer, bahwa komunikasi merupakan perbuatan, tingka laku dan kegiatan penyampaian lambang 
yang memperoleh makna. Adapun yang dimaksud dengan motivasi yaitu dorongan sikap dan nilai yang dapat mengubah dan mempengaruhi individi-individu untuk mencapai suatu tujuan yang spesifik sesuai dengan keinginan atau harapan seseorang. Dorongan sikap dan nilai tersebut adalah suatu hal yang invesibel yang dapat memberikan kekuatan dan dorongan individu bertingkah laku dalam hal mencapai tujuan, Rivai 2005 (dalam Maria 2013).

Puskesmas merupakan organisasi disektor publik yaitu organisasi yang memiliki tujuan untuk menghasilkan pelayanan kepada masyarakat, tanpa membedakan status dan kedudukannya.Organisasi disektor publik berorientasi pada kepentingan publik, yang tidak berorientasi pada laba sebagai tujuan akhirnya.Terkait dengan fungsi Puskesmas yang mempunyai peranan yang sangat penting dalam masyarakat oleh karena itu diperlukan upaya peningkatan kualitas pelayanan pegawai dalam melaksanan tugas kepada masyarakat.

Berdasarkan hasil observasi peneliti dan menurutsalah satu pasien yang berkunjung di Puskesmas Talise Kota Palu yang berinisial RR dan SR mengenai pelayanan pegawai di Puskesmas Talise Kota Palu sejauh ini masih belum ada yang maksimal, yaitu diantaranya adalah kualitas pelayanan yang diberikan pegawai belum memenuhi kriteria kepastian waktu, pelayanan masih membutuhkan prosedur atau proses yang berbelit-belit bahkan cenderung tidak peduli. Pegawai yang melayani pasien terkadang cemberut dalam pelayanan, dan ini sangat berkesan negatif terhadap pasien.Beberapa pasien mengeluh karena dokter Puskesmas dating tidak tepat waktu, sehingga pasien terpaksa harus menunggu lama.Hasil wawancara dengan pasien yang lagi menunggu untuk berobat yang berinisial DN, beberapa fakta yang sering meresahkan pasien diantaranya sikap tenaga kesehatan yang kurang ramah, dan simpati.Ketidaksempurnaan tenaga kesehatan dalam membangun komunikasi terhadap pasien tentunya dapat berakibat buruk terhadap kualitas pelayanan pegawai yang akhirnya dapat mengurangi kepuasan pasien.

Hasil observasi dan wawancara dengan pegawai yang berinisial NT diungkapkan bahwa ada beberapa pegawai yang terkadang masih belum mematuhi jam kerja yang berlaku di Puskesmas, mereka datang terlambat padahal sudah ada ketentuan waktu kerja setiap harinya. Ketidakdisiplinan pegawai diduga sebagai akibat tidak optimalnya komunikasi pimpinan kepada pegawai. Selanjutnya komunikasi antara pegawai dan pegawai yang lain kurang baik, dimana terkadang ada kesalah pahaman, perbedaan pendapat antar pegawai sehingga menyebabkan pegawai kurang maksimal dalam bekerja atau dalam pelayanan. Fungsi komunikasi yang menjembatani dan mengakomodir keinginan, keluhan dan aspirasi pegawai, kenyamanan lingkungan kerja yang masih belum optimal.

Motivasi juga merupakan salah satu faktor penentu kualitas pelayanan pegawai, sukses atau tidaknya suatu organisasi itu sangat tergantung dari aktivitas dan kreatifitas sumber daya manusianya. Jadi, hal yang sangat paling utama yang diperhatikan seorang pimpinan adalah membangkitkan gairah kerja atau semangat kerja pegawai.Tugas pimpinan sangatlah besar dalam memberi motivasi pegawai agar dapat bekerja sesuai program kerja yang ditetapkan oleh pihak Puskesmas. Puskesmas atau organisasi, baik yang sangat kecil ataupun yang sangat besar, para pegawai harus tetap bekerja sama sesuai dengan perintah pimpinannya. Perintah tersebut bisa saja tidak sesuai dengan keinginan bahkan sama sekali belum dimengerti oleh pegawai, dikarenakan pegawai belum pernah alami atau kerjakan sebelumnya. Akibatnya, timbulah perasaan malas dan tidak bergairah atau tidak semangat dalam bekerja.Perasaan malas tersebut sangat perlu untuk diwaspadai, karena bisa saja merupakan tanda-tanda hilangnya motivasi dalam diri pegawai (Arep dan Tanjung, 2003).

Hasil observasi dan wawancara dengan pegawai berinisial SL, fenomena motivasi berkaitan dengan sikap pimpinan kurang mengapresiasi pegawai yang memiliki prestasi yang baik, contohnya ketika ada salah satu pegawai teladan, tidak adanya apresiasi yang berarti yang diberikan pimpinan kepada pegawainya tersebut. Hal ini tentunya sangat mempengaruhi motivasi kerja pegawai.lagi pula pimpinan begitu kaku dalam melaksanakan perananya sebagai pimpinan, serta kurangnya keharmonisan atau 
hubungan yang baik antara pegawai yang satu dengan pegawai yang lain, kondisi dan keadaan sedemikian ini semakin menciutkan motivasi pegawai dalam menjalankan tugas yang telah dibebankan kepada mereka. Adapun tujuan dari penelitian ini yaitu untuk mengetahui dan menganalisis pengaruh komunikasi dan motivasi terhadap kualitas pelayanan pegawai di Puskesmas Talise Kota Palu baik secara serempak maupun secara parsial.

\section{KAJIAN LITERATURE DAN PENGEMBANGAN HIPOTESIS}

Komunikasi adalah faktor yang begitu sangat penting dalam upaya mencapai suatu tujuan organisasi. Komunikasi dapat pula diartikan sebagai proses mengirimkan dan menyampaikan suatu pesan untuk mencapai pemahaman secara bersama (Richard, 2009 dalam Noor, 2013). Menurut Rivai (2006) motivasi merupakan nilai dan sikap yang dapat mempengaruhi seseorang untuk mencapai suatu hal yang lebih spesifik sesuai dengan tujuan seseorang. Nilai dan sikap tersebut adalahsuatu hal yang sangat invesibel yang dapat memberikan kekuatan untuk mendorong seseorang bertingkahlaku untuk mencapai suatu tujuan. Rivai (2005) (dalam Maria, 2013) motivasi yaitu sebagai dorongan dan pembangkit gairah seseorang untuk melakukan tindakan suatu tindakan karena mereka ingin melakukan hal tersebut, McClelland (dalam Hapsir 2017). Menurut Nurmasitha (2009) pelayanan yaitu kegiatan, produk service, yang tidak berwujud dan tidak dapat dimiliki, tidak tahan lama tetapi dapat dialami dan dirasakan oleh yang penerima layanan.

\section{METODE PENELITIAN}

Penelitian ini jenisnya adalah penelitian deskriptif yaitu metode yang dilakukan dalam pencarian suatu objek, fakta, dan status sekelompok manusia, suatu kondisi, suatu sistem pemikiran ataupun suatu peristiwa pada masa sekarang dengan interprestasi yang tepat (Sedarmayanti dan Hidayat 2002). Jenis data yang dapat digunakan didalam penelitian ini adalah sebagai berikit: (1) Data kualitatif, yaitu data yang dapat dilihat berupa tulisan, bacaan yang digunakan dalam analisis deskriptif. (2)Data kuantitatif, yaitu berupa angka yang digunakan dalam penelitian ini.Sumber data yang dipakain didalam penelitian ini yaitu sebagai berikut: (1) Data primer, yaitu data yang didapatkan dari sumber pertama baik individu atau perseorangan seperti dari hasil dari wawancara atau dari hasil pengisian kuesioner yang biasa dapat dilakukan oleh peneliti. (2) Data sekunder, adalah data yang pengumpulan dan pengelolahannya dilakukan oleh orang lain dan digunakan sebagai sumber data tambahan.

Populasi yaitu himpunan atau keseluruhan karakteristik dari objek yang akan diteliti. Pengertian lain dari populasi yaitu keseluruhan dan totalitas objek psikologis yang dapat dibatasi oleh kriteria tertentu. Sedangkan yang dimaksud dengan sampel yaitu sekelompok kecil yang dapat diamati dan merupakan sebagian dari populasi sehingga sifat dan karakteristik dari populasi juga dimiliki oleh sampel (Sedarmayanti dan Hidayat 2002). Penelitian ini yang dimaksud dengan populasi adalah seluruh pegawai Puskesmas Talise Kota Palu.Berdasarkan data dari puskesmas talise jumlah pegawai adalah sebanyak 79 orang. Mengingat jumlah populasi yang relatif kecil yang terdiri dari PNS dan NON PNS dimana yang bekerja dipuskesmas sudah lebih dari 1 tahun dan mereka sudah paham dengan kondisi Puskesmas tersebut, maka seluruh populasi yang ada di Puskesmas Talise Kota Palu dijadikan responden atau disebut dengan penelitian sensus (Sugiono, 2004). Metode pengumpulan data yang digunakan adalah, (1) Observasi, yakni berupa penelitian lapangan terhadap karakteristik responden antara lain Komunikasi dan Motivasi terhadap Kualitas Pelayanan Pegawai Puskesmas Talise Kota Palu. (2) Kuesioner, yaitu Subjek yang diteliti dihubungi melalui daftar pertanyaan atau pernyataan secara tertulis yang diberikan kepada responden untuk mendapatkan jawaban tanggapan/respons menyangkut Komunikasi dan Motivasi terhadap Kualitas Pelayanan Pegawai Puskesmas Talise Kota Palu. (3) Dokumentasi, yaitu mencari data mengenai hal-hal serta variabel yang berupa catatan, transkip, buku surat kabar, majalah, agenda, dan 
sebagainya. Arikunto, 2006 (dalam Alam 2014).Tehniik dokumentasi dilakukan untuk mendapatkan informasi atau penjelasan tentang variabel yang digunakan dalam penelitian ini.(4) Wawancara, adalah mencari bahan (keterangan atau pendapat) melalui tanya jawab secara lisan dengan siapapun yang diperlukan dalam penelitian.

Instrumen pengukuran dapat dikatakan instrument yang valid jika suatu instrumen dapat mengukur sesuatu dengan tepat apa yang akan diukur (Suharsimi, 1993 dalam Muhidin dan Abdurahman 2007). Hal ini dimaksud untuk menentukan valid tidaknya item tersebut terhadap faktornya. Item yang mempunyai korelasi positif diatas nilai $r$ kritis $(0,30)$ menandakan bahwa item tersebut valid. Sugiyono, 2009 (dalam Helmi,2014).

Uji Normalitas berfungsi untuk menguji apakah dalam sebuah model suatu regresi, variabel independen dan keduanya mempunyai distribusi normal atau tidak. Model regresi yang baik yaitu distribusi data normal atau mendekati normal.Deteksi normalitas dilakukan dengan melihat penyebaran data (titik) pada sumbu diagonal dari grafik.

Uji Heterokedastitas berfungsi untuk menguji apakah didalam sebuah model suatu regresi, terjadi ketidaksamaan varians dari residul satu pengamatan ke pengamatan yang lain tetap, maka disebut homoskedastas.Jika varians tersebut berbeda, disebut heterokedastitas.Untuk mendeteksi adanya heterokedastitas yang dilakukan dengan melihat ada tidaknya pola tertentu dari grafik, dimana sumbu $\mathrm{X}$ yaitu $\mathrm{Y}$ yang telah diprediksi, dan sumbuh $\mathrm{X}$ adalah residul ( $\mathrm{Y}$ prediksi - Y sesungguhnya) yang telah distudentized.

Uji Multikolinieritas berfungsi untuk menguji apakah model regresi ditemukan adanya kolerasi antar independen.Jika terjadi kolerasi, maka dinamakan terdapat problem Multikolinieritas (multiko).Model regresi yang baik seharusnya tidak terjadi korelasi diantara variabel Independent.

Adapun rumus regresi yang digunakan adalah sebagai berikut:

$$
\mathbf{Y}=\mathbf{a}+\mathbf{b}_{1} \mathbf{X}_{1}+\mathbf{b}_{2} \mathbf{X}_{2}+\ldots+\mathbf{b}_{\mathbf{n}} \mathbf{X}_{\mathbf{n}}+\mathbf{e}
$$

Dimana:

$\mathrm{Y}=$ variabel terikat

$\mathrm{X}_{1}, \mathrm{X}_{2}, \mathrm{X}_{\mathrm{n}}=$ variabel bebas

$\mathrm{a}=$ konstanta dari persamaan regresi

$b_{1}, b_{2}, b_{n}=$ koefisien regresi dari variabel bebas $X$

$\mathrm{e}=$ nilai error

Rumus diatas apabila dikaitkan dengan penelitian ini akan diperoleh bentuk formulasi sebagai berikut:

$$
\mathbf{Y}=\mathbf{a}+\mathbf{b}_{1} \mathbf{X}_{1}+\mathbf{b}_{2} \mathbf{X}_{2}+\mathbf{e}
$$

Dimana:

$\mathrm{Y}=$ kualitas pelayanan

$\mathrm{X}_{1}=$ komunikasi

$\mathrm{X}_{2}=$ motivasi

$\mathrm{a}=$ konstanta regresi

$\mathrm{b}=$ koefisien regresi dari variabel bebas

$\mathrm{e}=$ nilai error

Uji Serempak (Uji F) dilakukan untuk mengetahui suatu tingkat signifikan pengaruh variabel independent secara serempak terhadap suatu variabel dependen. Agar mempercepat perhitungan dan agar mendapatkan hasil yang lebih akurat lagi, maka digunakan alat program bantu berupa SPSS versi 16. 
Uji Signifikan Parameter Individual (Uji Statistik T) dilakukan untuk mengetahui apakah dari masingmasing variabel independen secara parsial mempunyai pengaruh signifikan terhadap variabel dependen. Adapun kriteria yang dapat digunakan untuk melihat pengaruh satu variabel bebas secara parsial terhadap variabel terikat dalam uji t.

\section{Hasil dan Pembahasan}

Uji validitas dilakukan di Puskesmas Singgani Kota Palu dengan mengambil 22 orang, ditemukan bahwa seluruh item pertanyaan yang dituangkan dalam kuesioner penelitian seluruhnya dinyatakan valid. Hal ini ditunjukkan dengan nilai Corrected item total correlation lebih besar dari $0,3(\mathrm{r} \geq 0,3)$ dan tidak bernilai negatif. Berdasarkan perhitungan program SPSS, maka dapat dikatakan bahwa seluruh variabel penelitian dalam instrumen penelitian (kuesioner) menunjukkan nilai konsistensi atau reliabel yang layak karena memenuhi standar koefisien Alpha Cronbach lebih besar dari 0,6 ( $a \geq 0,6)$. Uji reliabilitas adalah mengukur suatu kuesioner yang merupakan indikator dari variabel. Suatu kuesioner dikatakan reliable dan handal jika jawaban seseorang terhadap pernyataan atau pernyataan adalah konsisten atau stabil dari waktu ke waktu ( Ghozali, 2005 dalam Hapsir 2017).Pengukuran reliabitas dilakukan dengan caraone shot atau pengukuran sekali saja dengan alat bantu SPSS uji statistic Cronbach alpha. Suatu konstruk atau variabel dikatakan reliable jika memberikan nilai Cronbach Apha > 0.60 (Ghozali, 2005 dalam Hapsir 2017).

Berdasarkan hasil uji reliabilitas yang telah digunakan, diketahui bahwa semua variabel (X1, X2, ,dan Y) mempunyai koefisien Cronbach's Alpha $\geq 0,60$, sehingga dapat dikatakan bahwa variabel penelitian yaitu Komunikasi (X1), Motivasi (X2), dan Kualitas Pelayanan (Y) dapat dikatakan konsisten dan akurat karna semua variabel memiliki Cronbach's Alpha $\geq 0,60$ sehingga alat pengumpulan data ini dapat dilakukan oleh orang yang sama dalam waktu yang berbeda atau digunakan oleh orang lain tetapi dalam waktu yang bersamaan atau waktu yang berbeda.

nilai suatu VIF dari variabel independen dalam model regresi yang dilakukan kurang dari angka 10 sedangkan nilai Tolerance lebih besar dari 0,10 , sehingga dapat dikatakan bahwa varaibel tersebut tidak terdapat gejala multikolinearitas. Asumsi non mulkolonearitas dalam model regresi yang digunakan terpenuhi, maka semua variabel memenuhi kriteria dan analisis dapat dilanjutkan.

Menurut Priyastama (2017) uji heterokedastistas yaitu keadaan yang mana dalam model regresi terjadi ketidaksamaan variansi dari residual pada satu pengamatan ke pengamatan yang lain.

Berdasarkan gambar diatas diketahui bahwa distribusi normal yang ditunjukkan pada titik-titik yang menyebar dan penyebarannya mengikuti arah garis diagonal sehingga dapat disimpulkan model regresi mengikuti asumsi normalitas.Menguji dan mengetahui kebenaran hipotesis dalam penelitian yang dilakukan di Puskesmas Talise Kota Palu, digunakan metode regresi linear berganda dengan menggunakan SPSS for windows versi 16.0. Hasil analisis tersebut dapat dilihat pada tabel 3 berikut:

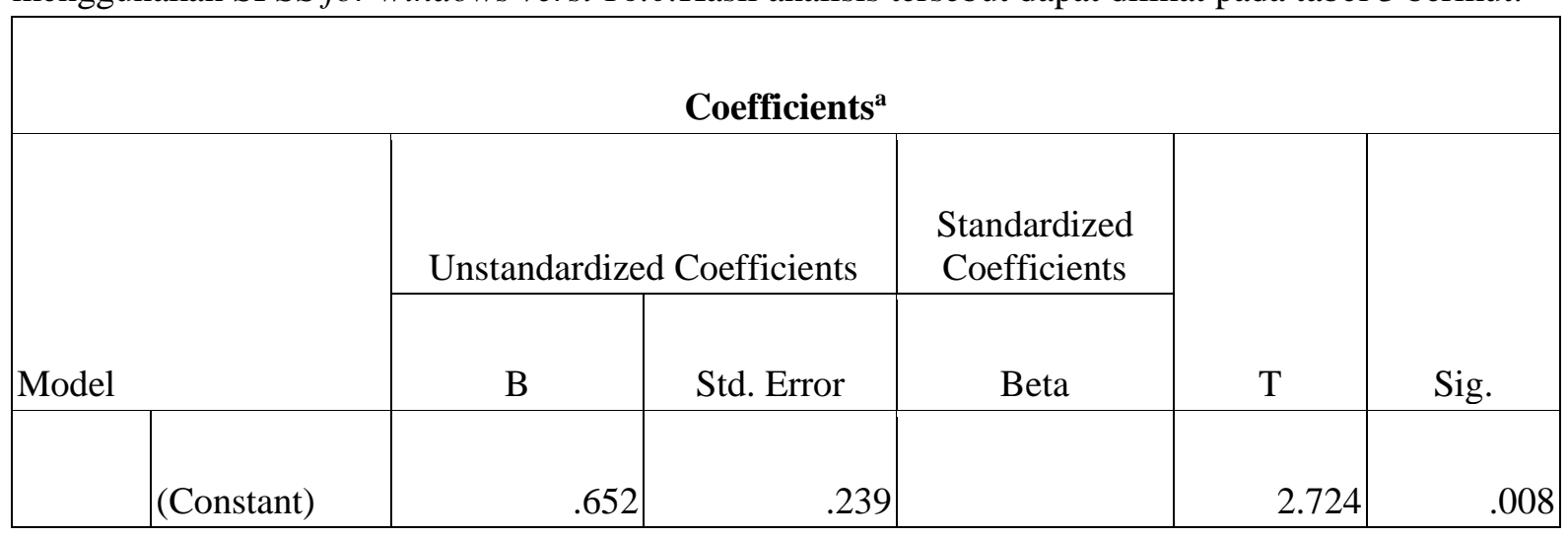




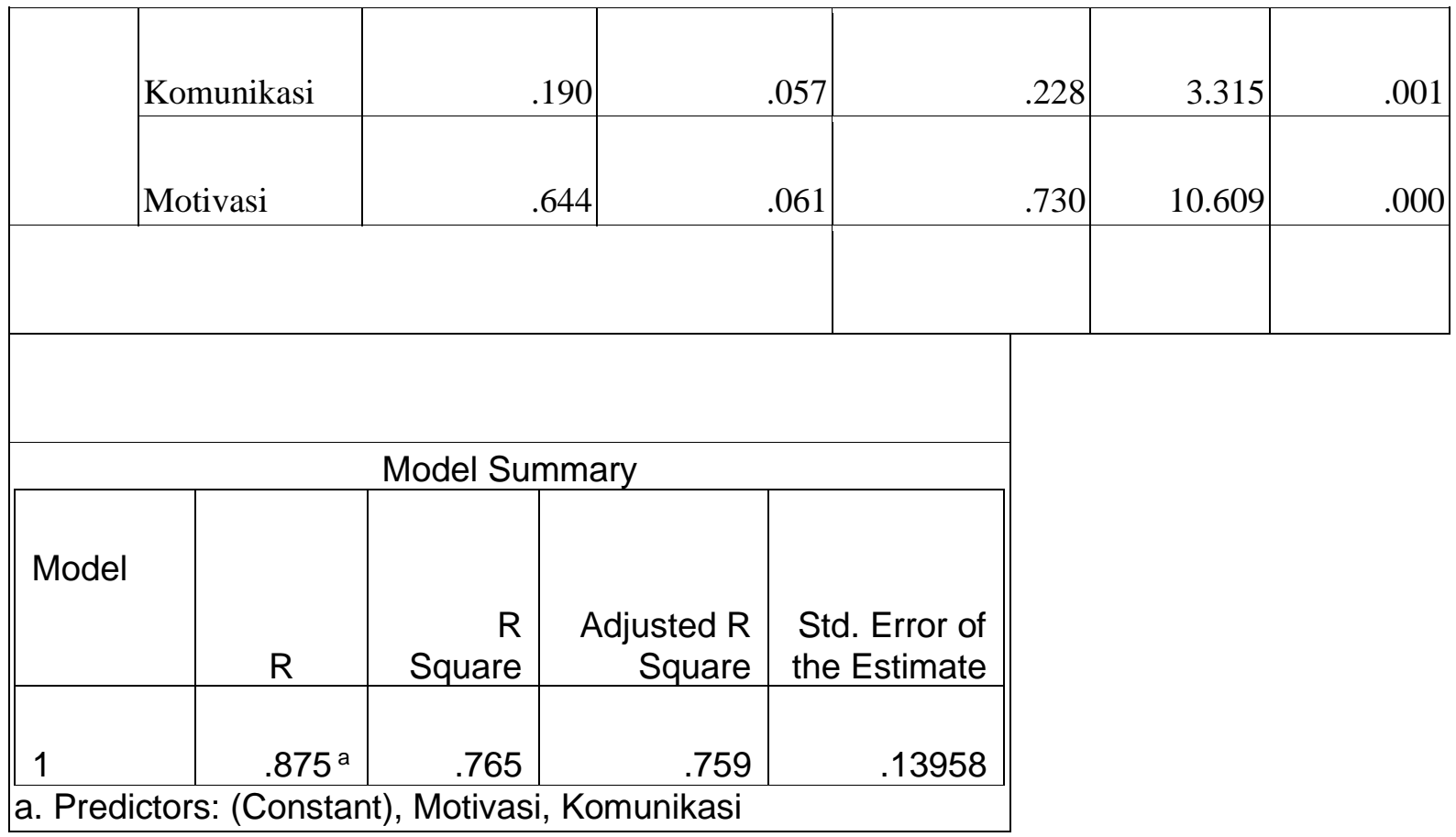

Persamaan linear yang dapat kita lihat digambarkan pada penelitian ini berdasarkan hasil analisis regresi berganda tersebut yaitu:

$$
Y=0,652+0,190 X_{1}+0,644 X_{2}+e
$$

Persamaan liniear diatas menunjukkan, variabel independen yang dianalisis berupa variabel $\left(\mathrm{X}_{1}, \mathrm{X}_{2}\right)$ memberi pengaruh terhadap variabel dependen (Y).Pengaruh signifikan secara serempak dan parsial dari variabel independen (komunikasi dan motivasi) terhadap variabel dependen (kualitas pelayanan), maka digunakan uji $\mathrm{F}$ dan uji $\mathrm{T}$. Pengambilan keputusan dalam uji hipotesis secara serempak dan parsial didasarkan pada nilai suatu probabilitas yang didapatkan dari hasil pengolahan data melalui program SPSS Statistik Parametrik sebagai berikut: (1) jika signifikan $<0,05$ maka, Ha diterima dan Ho ditolak yang berarti ada pengaruh yang signifikan antara variabel $\mathrm{X}$ dan $\mathrm{Y}$. (2) jika signifikan > 0,05 maka, Ha ditolak dan Ho diterima yang berarti tidak ada pengaruh yang signifikan antara variabel $\mathrm{X}$ dan $\mathrm{Y}$.

Uji F (serempak) adalah suatu metode untuk melihat apakah variabel independen (komunikasi dan motivasi) yang diteliti mempunyai pengaruh secara serempak terhadap variabel dependen (kualitas pelayanan). Agar lebih jelasnya dapat dilihat pada tabel berikut:

ANOVA $^{b}$

\begin{tabular}{|l|r|r|r|r|}
\hline Model & Sum of Squares & Df & Mean Square & \multicolumn{1}{c|}{ Sig. } \\
\hline Regression & 4.447 & 2 & & \\
\hline
\end{tabular}




\begin{tabular}{|l|r|r|r|l|}
\hline Residual & 1.364 & 70 & .019 & \\
\hline Total & 5.810 & 72 & & \\
\hline
\end{tabular}

Uji t digunakan untuk mengetahui apakah variabel independen yakni komunikasi dan motivasi yang diteliti memiliki pengaruh secara parsial terhadap variabel dependen yakni kualitas pelayanan, lebih jelasnya dapat dilihat pada tabel berikut:

\begin{tabular}{|c|c|c|c|c|c|}
\hline \multirow[t]{2}{*}{ Model } & \multicolumn{2}{|c|}{ Unstandardized Coefficients } & $\begin{array}{c}\text { Standardized } \\
\text { Coefficients }\end{array}$ & \multirow[t]{2}{*}{$\mathrm{t}$} & \multirow[t]{2}{*}{ Sig. } \\
\hline & B & Std. Error & Beta & & \\
\hline (Constant) & .652 & .239 & & .2 .724 & .008 \\
\hline Komunikasi & .190 & .057 & .228 & 3.315 & . 001 \\
\hline Motivasi & .644 & .061 & .730 & 10.609 & .000 \\
\hline
\end{tabular}

\section{a. Dependent Variable: Kualitas Pelayanan}

Berdasarkan dari hasil diatas dapat disimpulkan bahwa (1) variabel komunikasi ( $\left.\mathrm{X}_{1}\right)$, nilai signifikannya sebesar 0,01. Angka probabilitas signifikan $<0,05$ maka Ho ditolak dan Ha diterima, dengan demikian komunikasi berpengaruh terhadap kualitas pelayanan pegawai pada Puskesmas Talise Kota Palu. (2) motivasi $\left(\mathrm{X}_{2}\right)$ signifikan sebesar 0,00 karena Angka probabilitas signifikan $<0,05$ maka Ho ditolak dan Ha diterima, dengan demikian motivasi berpengaruh signifikan terhadap kualitas pelayanan pegawai pada Puskesmas Talise Kota Palu.

\section{Kesimpulan dan Saran}

Berdasarkan dari rumusan masalah, dari hipotesis dan pembahasan yang digunakan, maka disimpulkan bahwa: (1) Hasil analisis di peroleh bahwa variabel komunikasi $\left(\mathrm{X}_{1}\right)$ memiliki suatu koefisien regresi sebesar 0,190 dengan tingkat nilai signifikan 0,01. Hal ini menyimpulkan bahwa variabel komunikasi $\left(\mathrm{X}_{1}\right)$ memiliki pengaruh secara parsial terhadap kualitas pelayanan $(\mathrm{Y})$.sedangkan motivasi $\left(\mathrm{X}_{2}\right)$ yang memiliki nilai koefisien regresi sebesar 0,644 dengan tingkat signifikan 0,00. Hal ini menyimpulkan variabel motivasi $\left(\mathrm{X}_{2}\right)$ juga memiliki pengaruh secara parsial terhadap kualitas pelayanan.Berdasarkan penjelasan di atas dapat disimpulkan bahwa komunikasi $\left(\mathrm{X}_{1}\right)$ dan motivasi $\left(\mathrm{X}_{2}\right)$ memiliki pengaruh secara bersamasama terhadap kualitas pelayanan (Y). (2)Berdasarkan hasil dari setiap variabel, maka motivasi $\left(\mathrm{X}_{2}\right)$ yang memiliki nilai koefisien regresi sebesar 0,644 merupakan variabel dominan yang mempengaruhi kualitas 
pelayanan (Y). Berdasarkan hasil penelitian serta hal-hal yang terkait dengan keterbatasan penelitian, maka peneliti memberi saran sebagai berikut: (1) Hasil penelitian ini diharapkan dapat digunakan sebagai bahan masukan bagi Puskesmas Talise Kota Palu, untuk lebih memperhatikan komunikasi dan motivasi terutama dalam hal komunikasi pegawai. (2) Berdasarkan tanggapan responden terhadap variabel komunikasi, dimensi komunikasi ke bawah dengan indikator pimpinan dan pegawai terjalin hubungan yang baik adalah yang paling rendah. Oleh karena itu, diharapkan kepada pimpinan Puskesmas Talise Kota Palu kiranya meningkatkan hubungan yang baik antar sesama pegawai, sehingga pegawai merasa lebih terjalin persaudaraan sesama pegawai. (3) Berdasarkan tanggapan responden terhadap variabel motivasi, dimensi kebutuhan prestasi dengan indikator setiap pegawai merasa ada dorongan didalam diri untuk mencapai prestasi adalah yang paling rendah.Diharapkan kepada pimpinan Puskesmas Talise Kota Palu kiranya meningkatkan dorongan didalam diri pegawai untuk mencapai prestasi.Agar kinerja pegawai makin meningkat dan kualitas pelayanan yang diberikan semakin baik. (4) Berdasarkan tanggapan responden terhadap variabel kualitas pelayanan, dimensi reliability dengan indikator menyediakan layanan sesuai dengan waktu yang dijanjikan adalah paling rendah. Oleh karena itu, diharapkan kepada pegawai Puskesmas Talise Kota Palu kiranya memperbaiki proses pelayanan agar pelayanannya sesuai dengan waktu yang dijanjikan sehingga kualitas pelayanan yang diberikan semakin lebih baik. (5) Pada penelitipeneliti berikutnya yang memiliki ketertarikan untuk mengadakan riset serupa, diharapkan dapat mengembangkan hasil penelitian ini dengan memasukkan variabel-variabel lain diluar variabel ini.

\section{Referensi}

Alam, Syamsu, 2014. Pengaruh Komunikasi, Motivasi dan Disiplin Kerja Terhadap Kinerja Pegawai Lembaga Penjaminan Mutu Pendidikan Provinsi Sulawesi Tengah, Tesis Magister Tak Diterbitkan. Pascasarjana, Universitas Tadulako, Palu.

Arep, Ishak, dan Tanjung, Hendri, 2003. Manajemen Motivasi, PT Grasindo, Jakarta.

Hapsir, Mohammad, 2017. Pengaruh Komunikasi Layanan Dan Citra Perusahaan Terhadap Kepuasan Pelanggan Pencucian Mobil Qool It Dikota Palu, Tesis Magister Tak Diterbitkan. Pascasarjana, Universitas Tadulak, Palu.

Helmi, 2014.Pengaruh Motivasi Kerja Dan Disiplin Kerja Terhadap Kinerja Pegagai Dinas Peternakan dan Kesehatan Hewan Daerah Provinsi Sulawesi Tengah., Tesis Magister Tak Diterbitkan. Pascasarjana, Universitas Tadulako, Palu.

Laksana, Fajar, 2008. Manajemen Pemasaran Pendekatan Praktis, Graha Ilmu, Yokyakarta.

Maria, Siti, dan Saud, Udin, 2013. Pengaruh Motivasi Dan Kinerja Pegawai Terhadap Kualitas Layanan Administrasi Akademik. Jurnal administrasi pendidikan, Vol 18 (1), 147.

Muhidin, Ali dan Abdurahman Maman, 2007.Analisis Kolerasi Regresi dan Jalur dalam Penelitian, CV Pustaka Setia, Bandung.

Noor, Juliyansah, 2013. Penelitian Ilmu Manajemen, Prenada Media Group, Jakarta.

Noor, Juliyansah, 2013. Penelitian Ilmu Manajemen, Prenada Media Group, Jakarta.

Pangandaheng, Fony, 2015.Pengaruh Kualitas Layanan dan Citra Perusahaan Terhadap Kepuasan Pelanggan dan Dampaknya Terhadap Loyalitas Pelanggan Pada PT. Hadji Kalla Palu.Tesis Magister Tak Diterbitkan. Pascasarjana, Universitas Tadulako, Palu.

Prismeiningrum, Maria, 2015. Pengaruh Komunikasi Terapeutik Terhadap Kualitas Pelayanan Perawat (Persepsi Perawat Pada Rs Kusta Donorojo Jepara), Skripsi Sarjana Tak Diterbitkan, Fakultas Ilmu Pendidikan Universitas Negeri Semarang, Semarang. 
Priyastama, Romie, 2017. Buku Sakti Kuasai SPSS, Start Up, Yogyakarta.

Rivai, 2006.Manajemen Sumber Daya Manusia Untuk Perusahaan Dari Teori Ke Praktik.PT.Rajagrafindo Persada, Jakarta.

Sedarmayanti dan Hidayat Syarifudin, 2002.Metodologi Penelitian.CV Mandar Maju, Bandung. Sugiyono, 2004.Metode Penelitian Bisnis.CV Alfabeta, Bandung.

Sutrisno, Edy, 2009. Manajemen Sumber Daya Manusia, Kencana, Jakarta. 